\title{
October 26 Highlight and Commentary
}

\section{Treatment of pseudobulbar affect in ALS}

The Brooks et al. controlled clinical trial found that dextromethorphan and quinidine, compared with either drug alone, safely reduced the severity and frequency of pseudobulbar affect (pathologic laughing and crying) episodes in amyotrophic lateral sclerosis (ALS) patients. They also demonstrated an improvement in quality of life related to treatment.

see page 1364

\section{AVP-39: A successful randomized clinical trial on a supportive therapy for ALS}

Commentary by Jonathan Katz, MD

Pseudobulbar affect is a term used to describe uncontrolled episodes of laughter or crying. These emotional outbursts occur in a large number of patients with ALS and can be a major problem in their interpersonal interactions. ${ }^{1}$

The above report by Brooks et al. describes a 17-center, doubleblind, randomized, controlled clinical trial showing that AVP-39 (a combination of $30 \mathrm{mg}$ of quinidine and $30 \mathrm{mg}$ of dextromethorphan) relieved emotional lability in ALS patients with pseudobulbar affect and that this relief improved quality of life and quality of relationship scales.

An important implication of the present article is that despite numerous clinical trials, few agents have been of obvious benefit for this difficult disorder. Only riluzole has been approved by the FDA for use in the United States based on two clinical trials that demonstrated a modest effect on survival in the mid-1990s. ${ }^{2}$ The AVP-39 study is also of particular interest in that it uses a doubleblind, randomized trial to determine the benefit of a supportive measure, as opposed to an effect on survival. These results will allow practitioners to make specific judgments with the knowledge of what outcome measures were used, the magnitude of the benefits, and the nature of risks. Additional trials are needed for studying and comparing the benefits of other agents that may treat pseudobulbar affect and other supportive measures commonly used in ALS patients: the role of physical therapy, exercise, and respiratory failure, and medical therapies for sleep, depression, pain, excess salivation, respiratory failure, cramps, and spasticity.

Finally, a successful randomized trial such as this one should prompt us to consider some of the practical limitations of evidence-based medicine. While trials provide us with evidence that a therapy is effective, they do not give guidance on how to weigh monetary costs or make subjective judgments about the cost of side effects and the value of the clinical improvement. For example, the release of riluzole onto the market led to debate regarding its overall utility because of its high cost, the need to monitor for adverse reactions, and its relatively modest benefit. ${ }^{3}$ In the current study, patients had to be tested to determine how they metabolized dextromethorphan, $89 \%$ of patients experienced untoward side effects, and $24 \%$ discontinued therapy during the trial's 4-week duration. These concerns will raise questions about AVP-39 acceptability in the context of other agents that may improve pseudobulbar affect, including amitriptyline and serotonin reuptake inhibitors, but have not yet been as carefully studied.

\section{References}

1. Gallagher JP. Pathological laughter and crying in ALS: a search for their origin. Acta Neurol Scand 1989;80:114-117.

2. Miller RG, Bouchard JP, Duquette P, et al. Clinical trials of riluzole in patients with ALS. ALS/Riluzole Study Group-II. Neurology 1996;47(suppl 2):S86-90.

3. Miller RG, Mitchell JD, Lyon M, Moore DH. Riluzole for amyotrophic lateral sclerosis (ALS)/motor neuron disease (MND). Amyotroph Lateral Scler Other Motor Neuron Disord 2003;4:191-206.

see page 1364 


\section{Neurology}

October 26 Highlight and Commentary

Neurology 2004;63;1345

DOI 10.1212/01.WNL.0000145385.55983.1E

This information is current as of October 25, 2004

\section{Updated Information \&} Services

References

Citations

Permissions \& Licensing

Reprints including high resolution figures, can be found at: http://n.neurology.org/content/63/8/1345.full

This article cites 3 articles, 0 of which you can access for free at: http://n.neurology.org/content/63/8/1345.full\#ref-list-1

This article has been cited by 1 HighWire-hosted articles: http://n.neurology.org/content/63/8/1345.full\#\#otherarticles

Information about reproducing this article in parts (figures,tables) or in its entirety can be found online at:

http://www.neurology.org/about/about_the_journal\#permissions

Information about ordering reprints can be found online:

http://n.neurology.org/subscribers/advertise

Neurology ${ }^{\circledR}$ is the official journal of the American Academy of Neurology. Published continuously since 1951, it is now a weekly with 48 issues per year. Copyright . All rights reserved. Print ISSN: 0028-3878. Online ISSN: 1526-632X.

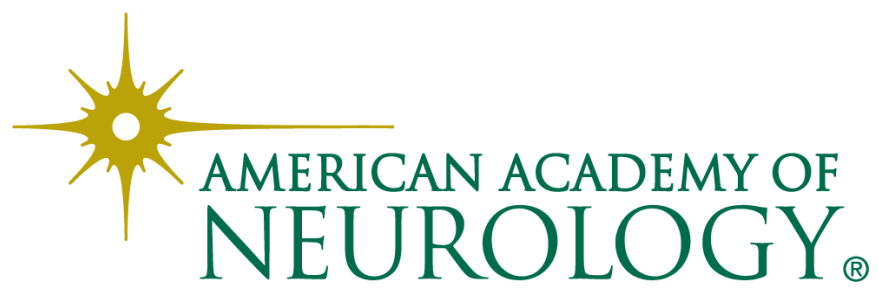

